\title{
Rebuilding local foods in Appalachia: Variables affecting distribution methods of
}

\section{West Virginia farms}

*James Robert Farmer ${ }^{a}$ and Megan Elizabeth Betz ${ }^{b}$

${ }^{a}$ Department of Recreation, Park, and Tourism Studies; Vincent and Elinor Ostrom

Workshop in Political Theory and Policy Analysis, 1025 E. $7^{\text {th }}$ St., SPH 133, Indiana

University, Bloomington, United States, 47405. jafarmer@indiana.edu, 812-856-0969.

${ }^{b}$ Department of Geography, 701 E. Kirkwood Ave., Indiana University, Bloomington,

United States, 47405. mebetz@indiana.edu 
1 Abstract: Across the United States, farms are consolidating and fewer individuals earn

2 their sole income from agriculture. At the same time, the number of very small farms-

3 many of which engage in direct-to-consumer sales strategies - is on the rise. While much

4 research has explored issues of size and scale for farms transitioning to organic

5 certification, this study aims to elucidate the variables that predict whether farmers sell

6 directly to consumers or through indirect methods such as food hubs, wholesalers,

7 schools, and other institutions. Using a mailed survey to West Virginian farmers, this

8 research attempted to better understand the similarities and differences between farms

9 that produce specialty crops and animal products geared for local distribution via direct-

10 and non-direct-to-consumer method of distribution. The goal of this research was to

11 highlight variables that may affect the scaling of operations to include distribution

12 methods beyond direct-to-consumer. To this end, a postal survey was sent to a list of

13 West Virginia farmers focused on local distribution: specialty crop and animal producers

14 were the focus of our list development. A total of 219 participants responded to the

15 survey (29.2\% response rate). After cleaning the dataset for the current analysis, 190

16 surveys were deemed useable. Regression analysis of survey data found that farmers

17 selling through only direct-to-consumer strategies were more concerned about how their

18 farming practices affected the environment, the production of high quality foods, and

19 health risks associated with chemical usage; they were also more willing to try new

20 methods than their non-direct counterparts. Additionally, higher levels of economic

21 dependence on items such as costs of credit, loan availability, etc. was also a significant

22 variable in predicting distribution type. Finally, our results indicate that farmers who are

23 distributing food through non-direct means are demographically distinct from their local- 
24 only counterparts on a number of measures, including, most critically: educational

25 attainment (-), acres farmed (+), and length of family ownership (+). Taken together,

26 these variables point to access to land and capital as determinants of scale and marketing

27 strategy.

28

29 Keywords: LOCAL FOOD SYSTEMS; DIRECT-TO-CONSUMER; DISTRIBUTION

30 SCHEMES; WEST VIRGINIA; CENTRAL APPALACHIA; WHOLESALE

31 DISTRIBUTION 


\section{$32 \quad$ 1. Introduction}

33 In the U.S., farms have continued to decrease in number and increase in size over

34 the last three decades (USDA, 2013). This shift has generally involved mid-sized farms

35 being assimilated into larger farms, but reports also suggest that there has simultaneously

36 been a sharp increase in the number of very small farms, or "microfarms" (ibid). Many of

37 these farms engage in direct-to-consumer sales strategies, from farmers' markets and

38 farm stands to community-supported agriculture (CSA). ${ }^{1}$ While farms selling directly to

39 consumers are helpful in terms of rebuilding local food systems, increasing food security,

40 and reestablishing a culture around food and agriculture (Alkon, 2008; Allen, 2010;

41 Connell et al., 2008; Hinrichs, 2003), they continue to support a niche market of

42 consumers (Farmer et al., 2014). The shortened supply chains result in increased gains for

43 farmers, who often work across stakeholders to remove institutional barriers (Marsden, et

44 al., 2000). This has led to the rise of the "locavore" and increased interest in local food as

45 a tool for community and economic development. ${ }^{2}$

$46 \quad$ While studying food purchasing in rural and urban communities in the United

47 Kingdom, Winter (2003) found "an ideology of localism based on sympathy for farmers,

48 an ideology equally at home amongst outside incomers as more established rural

49 residents" (p. 29). This ideology was embedded in location as well, with rural areas

\footnotetext{
${ }^{1}$ In the CSA model, consumers become members of the farm by paying one advanced payment for a present number of weeks' produce; these members then pick up their produce and, due to the up-front payment, share in the risks of poor weather, pests, and low yields (Galt, et al., 2012).

2 The term locavore was coined by four women in the San Francisco Bay area to connote a diet in which one purchases food produced within 100 miles of their home for the sake of conserving fossil fuels, preserving the environment, and supporting the local economy (Wu, 2005).
} 
50 purchasing local produce more frequently than metropolitan areas (ibid). Such purchasing

51 is often said to be driven by a desire to support the local economy (Brown, 2002; Winter,

52 2003). As such, local food is a way to earn a sufficient living rather than make a great

53 profit, though it can earn farmers price premiums (Paloviita, 2010; Veldstra et al., 2014).

54 In this way, produce farmers who choose to focus on local markets share many of

55 the same hurdles and advantages as those who choose to operate organic farms where

56 premiums are largely driven by crop perishability; these factors also make flexibility in

57 marketing strategies an essential component of local and organic produce enterprises

58 (LeRoux et al., 2010). Fresh produce continues to dominate organic sales and is at the

59 core of conversations about local food, but Dimitri and Greene (2000) have aptly noted

60 that "net returns to various production systems may vary with biophysical and economic

61 factors (such as soil type, climate, and proximity to markets), and a system that is optimal

62 in one location may not be optimal in another" (p. 4).While wholesalers and retailers

63 view organic as a "seller's market" and consumer demand is growing, adequate

64 infrastructure, certification, and quantity continue to function as barriers to fulfilling

65 current levels of demand (Dimitri and Oberholtzer, 2009; Johnson and Endres, 2012).

66 Farmers focusing their efforts on local markets face similar hurdles, as the farms largely

67 sell fresh produce that must reach consumers quickly; however, the inability to offer

68 consistent, year-round demand limits the degree to which consumers can depend on their

69 produce. Where possible, direct-to-consumer marketing strategies enable small-scale

70 farmers to avoid limitations of third-party certification and other structural barriers; these

71 farmers "face unique challenges in meeting and verifying wholesale post-harvest

72 handling standards" (Day-Farnsworth et al., 2009, p. 12). Additionally, different sales 
73 strategies offer different returns;CSAs offer the highest returns, followed by unstaffed

74 farm stands and farmers' markets, while wholesale (not-direct-to-consumer) offers the

75 lowest returns (LeRoux et al., 2010). As a result, small- to medium-scale famers must

76 manage a complicated portfolio of risks. If local purchasing programs from farmers'

77 markets to food hubs may begin to shift us toward a food system that supports producers

78 (Campbell and MacRae, 2013), infrastructure is needed to ensure local producers and

79 consumers have access to each other.

80 Direct-to-consumer options may be more critical at smaller scales, as increased

81 farm size is closely linked to increased access to capital. Feenstra, et al. (2011) wrote:

82 The midsize farmer who has been in business longer and is better capitalized can

83 afford to take the risk of trying an unproven values-based marketing channel,

84 especially since she probably has alternatives ways to get to market should the

85 new channel not work out. (p. 51)

86 The value-laden direct-to-consumer system, and consumers' willingness to pay price

87 premiums, means that direct sales have a significant positive impact on gross sales (Detre

88 et al., 2011). Opting for a mixed marketing model may help farmers capitalize on the

89 benefits of both: the immediacy of direct-to-consumer and the stability and larger scale of

90 mediated sales. According to Park (2009), farmers new to the business specialize in one

91 marketing strategy; with experience comes diversification of distribution strategies. This

92 reinforces Lyson et al. (1995), who found that while full-time farmers use multiple

93 outlets, part-time and non-growers often only use farmers' markets. These non-growers,

94 craftspeople selling non-food goods or processed goods made from foods they did not

95 grow, are not of interest here, as this research prioritizes farmers, and therefore growers. 
96 Scale of business operations, as well as farm acreage, inform selection of farm

97 distribution model. Community-wide, average farm scale may limit access to particular

98 distribution models. For example, Day-Farnsworth et al. (2009) note that a lack of

99 investment capital may limit the ability to start aggregation and distribution businesses at

100 the local or regional level. Unfortunately, it is at this level that aggregation services are

101 most important for small-scale farmers who choose not to sell directly to consumers.

102 Turning to larger-scale aggregation services, in which produce from multiple farms is

103 sold together with no farm name or description, result in a loss of farm identity, which

104 simultaneously results in a loss of value (Day-Farnsworth et al., 2009).

105 Hardesty and Leff (2009) argued, "Direct marketing channels can provide several

106 other benefits to producers. Market diversification is a classic risk spreading tool in all

107 industries, including agriculture. Direct marketing increases the number of marketing

108 options available to farmers" (p. 33). Selecting a marketing strategy and farming practice

109 involves considerable weighing of risks. For example, direct-to-consumer price

110 premiums may be offset by increased marketing costs; working with a wholesaler, on the

111 other hand, offers the greatest returns on marketing costs (Hardesty and Leff, 2009).

112 Balancing these risks is tied to access to markets. Verhaegen and Van Huylenbroeck

113 (2001) claimed, "Since conventional marketing channels are based on industrial co-

114 ordination, quality efforts that are not reflected in tangible features of the product are not

115 financially rewarded...” (p. 444). However, Hanson et al. (2004) have countered that

116 organic farmers reported facing fewer risks than conventional farmers because they are

117 not dependent on chemical inputs. Koesling et al. (2004) and Läpple (2012) found

118 organic farmers to be less risk-averse than conventional farmers, as their limited 
119 application of chemical additives may result in lower yields and increased loss due to

120 pests or extreme weather. Those not certified organic risk losing out on price premiums

121 through traditional distribution strategies, particularly for small-scale farmers with highly

122 perishable produce. This market-based risk is significant and weighs more heavily on

123 those more dependent on farm income (Koesling et al., 2004). Small-scale farmers who

124 are not certified organic but practice the methods risk a loss in the price point accrued

125 through direct markets, particularly if their product enters a traditional wholesale system

126 where chain of custody is not presented to the end consumer (Veldstra et al., 2014). Their

127 product would therefore be considered as conventional as that of a farmer using

128 traditional herbicide/pesticide treatments to promote higher yields.

129 While much research has pointed to the issues of size and scale for transitions to

130 organic certification (Veldstra et al., 2014; Farmer et al., 2014; Cranfield et al., 2010),

131 little research has been done on farmers drawing on similar environmental and

132 community values, along with price premiums, to prioritize local sales. This research

133 aims to elucidate the variables that predict whether farmers sell directly to consumers or

134 through non-direct-to-consumer methods-distribution frameworks that include food

135 hubs, wholesalers, schools, and other institutions. By attempting to better understand the

136 similarities and differences between farms, we hope to highlight variables that may affect

137 the scaling of operations for distribution methods beyond direct-to-consumer. Our

138 primary research question asks:

139 What variables most predict which West Virginian farmers sell directly to $140 \quad$ consumers and which use non-direct-to-consumer venues such as wholesalers

141 distributing locally, local grocers, and restaurants? 
142 Based on the type of agriculture that exists in this region, this research addressed

143 production of specialty crops and animal products geared for local distribution. We

144 believe this research will assist local food advocates, farmers, policy makers, and other

145 professionals seeking to further develop local food systems beyond direct-to-consumer

146 sales.

147 West Virginia farmers are an important group to consider given the states

148 proximity to several metropolitan areas (Washington DC, Baltimore, Maryland, and

149 Pittsburgh, Pennsylvania) and the frequency of small farms in the state (ranking first in

150 the U.S., per capita) in the rural state. In general WV farms are small (69.6 hectares)

151 when compared to the national average 178.5 hectares (NASS, 2004). Farmland prices,

152 over the past several decades, cost more than their agricultural value would suggest,

153 particularly in areas close to sizeable urban populations (Shi et al., 1997). Additionally,

154 West Virginia ranks 49/50 for average household income, indicating the need for

155 consumers to prudently make spending decisions. Coupling the two former variables

156 together, farmers are forced to maximize the per acre return garnered in their farming

157 operations in order to economically sustain their operations and lifestyle (Brown, Miller,

158 Boone, Boone, Gartin et al., 2007), all the while considering a price ceiling for

159 specialized farm products. One approach to achieving this maximization is through local

160 and/or direct to consumer sales.

161 The agricultural policy landscape of the U.S. and the physical landscape of West

162 Virginia have resulted in a distinct farming culture in the state, making it a unique site for

163 exploring farmers' motivations for selling through various distribution strategies. West

164 Virginia's topography and soil fertility make large-scale agriculture impossible in many 
165 parts of the state, while low population density makes direct-to-consumer sales

166 unprofitable for many farmers. West Virginia has the largest number of small farms (less

167 than $\$ 350,000$ gross income per year) per capita, resulting in small-scale agriculture that

168 is distinct in the U.S. for its disproportionate amount of specialty crop agriculture. Peters

169 et al. (2012) reported that there is sufficient space for production to meet the state's

170 demand for fruits and vegetables; however, logistical and marketing hurdles in getting

171 produce to consumers mean there is little motivation for farmers to expand production.

172 While the state is positioned between several large metropolitan areas with some farms

173 serving large metro areas in surrounding states, its rurality makes access to consumers

174 and aggregation complicated.

175 Previous research by Farmer et al. (2014) found that while only 4 WV farms that

176 were surveyed were certified organic, 91 farms self-identified as organic or "beyond

177 organic." Fairweather and Campbell (1996) proposed five criteria that keep farmers from

178 organic agriculture: not knowing about organic, being well satisfied with current yields or

179 the farm's appearance, being well satisfied with a low-input system they are already

180 using, thinking organic farming is not technically or financially viable, thinking organic

181 farming is not sustainable. Many of these same factors may be at work among West

182 Virginian farmers choosing a mix of direct-to-consumer and mediated distribution

183 strategies, informing how they weigh risk and make decisions regarding distribution

184 strategies. Johnson and Endres (2012) identified several core structural barriers that limit

185 small-scale farmers' ability to enter the marketplace, which include: capacity limitations,

186 a lack of traceback mechanisms, and a lack of certified commercial kitchens and

187 processing facilities. Additionally, farmers struggle to keep track of federal rules and 
188 regulations (ibid). Many of these barriers can be avoided by selling directly to the

189 consumer, which gives farmers flexibility in terms of scale and branding. Engagement

190 with the consumer enables them to describe their farm practices without being bound to

191 organic standards and labeling to obtain price premiums.

192 If the supply of local (which is often comprised of organic) goods is to increase

193 and fulfill demand, additional research must be conducted to understand the risks,

194 limitations, and motivations that drive farmers' choices in agricultural practice and

195 distribution. Furthermore, if farmers are to embrace the uncertainty of alternative

196 agricultural models, then farmers' conceptualization and internalization of institutional

197 barriers must be better understood. This research represents a first step to better

198 understanding these factors and the ways in which scale, access to land, access to capital,

199 and farm history inform an operation's marketing strategies.

200

201 2. Materials and Methods

$202 \quad 2.1 \quad$ Study Site

203 This state-wide study was conducted in West Virginia, a state located in the heart of

204 central Appalachia in the eastern United States. 1,855,413 residents lived in West

205 Virginia in 2012, and the state ranked $49^{\text {th }}$ for median household income. West Virginia

206 is an exceptional site for studying farmers growing for local distribution given its

207 proportion of "small" farms and topography that is more conducive to the growing of

208 specialty crops than traditional commodity row crops. While small-farms and specialty

209 crops are not always synonymous, the two overlap much for the current study and site.

210 West Virginia's 23,618 farms average 157 acres compared to the 418-acre average U.S. 
211 farm (USDA, 2007a): it has the largest number of small farms of any state. It was also

212 one of 22 states that saw a $5.1 \%$ or greater increase in the number of farms between 2002

213 and 2007 (ibid). Parts of West Virginia, particularly those most known for farming, are

214 relatively close to major metropolitan areas, including Pittsburgh, PA; Columbus, OH;

215 Richmond, VA; Washington, DC; and Baltimore, MD.

216 West Virginia is dominated by forested mountains, a challenging landscape for

217 traditional row-crop agriculture; however, agricultural regions are found throughout the

218 state in its river valleys (along the Ohio River), the northern (near Morgantown) and

219 eastern (nearing the Baltimore/Washington, DC, area) panhandle regions, and in the

220 southeastern rolling hills of Greenbrier and Monroe Counties. West Virginia's sloping

221 topography lends itself to orchards and other types of fruit production, as well as

222 specialty crops, which include "fruits and vegetables, tree nuts, dried fruits, horticulture,

223 and nursery crops (including floriculture)," and which "must be intensively cultivated and

224 used by people for food, medicinal purposes, and/or aesthetic gratification to be

225 considered specialty crops" (USDA, 2013).

$2262.2 \quad$ Research Design

227 This research project was based on a two-phase sequentially embedded mixed-

228 methods research design according to Creswell and Clark (2007) and was similar to a

229 study of organic dairy farmers conducted by Cranfield et al.'s (2010). Interviews were

230 initially conducted with 14 West Virginia farmers in order to develop a contextually

231 relevant questionnaire. The instrument, a postal mailed survey, was then administered to

232 as many West Virginia farmers as could be identified. The mixed methods approach

233 allowed for one step to inform the development of the next, as well as for one method to 
234 complement the limitations of another (Greene et al., 1989). While the survey provided

235 breadth, the interviews provided depth. A detailed reporting of the interview methods and

236 results can be found in the Farmer et al. (2013). This paper presents the results of

237 analyses from the Phase 2 survey.

238

\section{$2392.3 \quad$ Instrument Development and Administration}

240 The questionnaire was developed based on the analysis of interview data and a

241 review of current literature. The questionnaire had five sections. Section 1 solicited

242 operational information such as farm type (organic, certified organic, in transition,

243 exempt, conventional, and other), acreage, farm products, farm income, soil type and

244 fertility, and participation in government programs. Section 2 contained questions and

245 prompts developed from the phase 1 interviews and a literature review that pertained to

246 production methods, farming philosophy, and risk perception prompts, many of which

247 were based on Koesling et al.'s (2004) research. Section 3 gathered details on market

248 variables and outlets, such as the city/town where farm products are distributed,

249 perceived demand for certified organic products in the area, and distribution venues.

250 Section 4 of the instrument solicited data and perspectives on USDA organic

251 certification. Section 5 included demographic questions. The questionnaire underwent

252 review and revision, with comments solicited from research scientists and an expert panel

253 comprised of conventional, organic, and specialty-crop farmers.

254 The research team used a variety of mechanisms to compile a list of West

255 Virginia farmers focused on local distribution: specialty crop and animal producers were

256 the focus of our list development. A participant list from a conference organized by the 
257 West Virginia Small Farm Center supplied the greatest number of contacts. This was

258 supplemented with contact information from the online Local Harvest database

259 (http://www.localharvest.org), information from all West Virginia farmers' markets,

260 through open recruitment at farm and food meetings and conferences in Huntington and

261 Morgantown, through the West Virginia Small Farm Advocate periodical, the West

262 Virginia Department of Agriculture (WVDA), the West Virginia Farmers Market

263 Association, e-mail announcements by the West Virginia Food \& Farm Coalition, and the

264 researchers' personal contacts. Our lack of access to a complete list of West Virginia

265 farmers, which does note exist, limits the generalizability of our results and lessens the

266 conclusion that can be made.

267 We used a modified Tailored Design Method for the distribution of the mailed 268 questionnaire (Dillman et al., 2011). Mailings were spaced according to Dillman et al.

269 (2011), and included four separate posts that occurred between January 25, 2012 and

270 February 14, 2012. Post 1 included a letter of invitation to partake in the study by

271 completing the ensuing questionnaire. Post 2 included a copy of the questionnaire and a

272 pre-stamped/addressed envelope for the return. Post 3 included a reminder post card and

273 post 4 included a reminder post card. No incentive was provided. Returned-completed

274 questionnaires were entered into a database. A total of 884 questionnaires were mailed to

275 potential participants. Sixty-five questionnaires were returned for insufficient addresses,

276 and 68 were returned because the recipient no longer qualified to participate in the study.

277 The remaining 751 addresses were deemed valid.

278

$2792.4 \quad$ Data Analyses 
This current analysis expands from the previous work of Farmer et al. (2014),

281 who focused on the decision to certify or grow organically. We used SPSS 23.0 to

282 analyze the data. Descriptive statistics were used to create mean and frequency scores for

283 demographic variables and farm characteristics. Chi-square and ANOVAs were

284 employed to compare the two groups of farmers (those distributing directly and those

285 who also used non-direct distribution means). Principal component analyses (PCA) were

286 used to understand relationships between various items in each scale and to assist with

287 the creation of composite variables for further analysis. Components from the PCA that

288 were returned with Eigenvalues greater than 1, sufficient loading above 0.300, and

289 acceptable reliability levels with a Cronbach's alpha score greater than .70 were retained.

290 Finally, a binary stepwise logistic regression was used to understand what factors related

291 to the farmers' choice to distribute through direct-to-consumer venues only or to use non-

292 direct distribution approaches.

294 3. Results

$295 \quad 3.1 \quad$ Ag Census \& Survey Response Overview

296 A total of 219 participants responded to the survey (29.2\% response rate). After

297 cleaning the dataset for the current analysis, 190 surveys were deemed useable.

298 Considering a few census demographics and farm data points is useful in providing

299 context for West Virginia farmers and for the interpretation of our results. According to

300 the USDA (2007b) Agricultural Census, 52.5\% of farms in the state earned less than

$301 \$ 2,500$ and $67.7 \%$ earned less than $\$ 5,000$ annually. The average age of a West Virginian

302 farmer was 58.1, and $99.76 \%$ of them identified themselves as white on the USDA 
303 (2007b) Agricultural Census. Women are the primary operators of approximately $13.6 \%$

304 of farms. The mean farm size in the state is 157 acres with $65.7 \%$ of farmers holding an

305 off-the-farm job.

306

$307 \quad 3.2 \quad$ Participant Profile

308 Based on our categorization of respondents according to the dichotomous variable

309 encompassing distribution venues, $40.5 \%(n=77)$ sold directly to consumers only, while

$31059.3 \%(\mathrm{n}=112)$ distributed in some manner to other institutions that in turn sold directly

311 to consumers. Table 1 provides a comparison of demographic and farm characteristics

312 between the two groups. The average respondent age was 55.33, and they had been

313 involved in farming operations for a mean of 24 years (minimum of 2 and maximum of

314 90). Most had at minimum earned a bachelor's degree (60.4\%), while $3.2 \%$ did not

315 complete high school. 97.3\% identified as white. Most household incomes fell between

$316 \$ 20,000$ and $\$ 60,000(52.9 \%)$ with $38.2 \%$ exceeding $\$ 60,000$. Respondents indicated that

317 an average of $22.05 \%$ of their household income was derived from farming operations,

318 while over $61 \%$ of households held an off-the-farm job. Most (68.4\%) respondents were

319 the first generation of their family on the land they farmed, while 26 respondents (13.9\%)

320 indicated that their family had been on the land for more than four generations. One

321 individual indicated his family had been on the land prior to the Revolutionary War. Most

322 respondents grew up in a rural setting $(63.2 \%)$, while $36.7 \%$ grew up in either a suburban

323 or urban setting. The majority of individuals had no agricultural training or education

$324(55.9 \%)$.

Table 1. Descriptive and comparison results of demographic and farm characteristic data overall and between groups. 


\begin{tabular}{llll}
\hline Category & Subcategory & $\begin{array}{l}\text { Direct Only } \\
(\mathrm{n}=77)\end{array}$ & $\begin{array}{l}\text { Non-Direct Sales } \\
(\mathrm{n}=112)\end{array}$ \\
\hline Average Age & & 53.44 & 56.60 \\
Years Farming*** & No H.S. Diploma & 18.86 & 27.37 \\
Education & 2 & 4 \\
& $\begin{array}{l}\text { Some College/Training } \\
\text { B.S. Degree }\end{array}$ & 20 & 46 \\
& Graduate Degree & 30 & 29 \\
Ethnicity & white & 73 & 30 \\
& Other & 2 & 109 \\
Off-Farm-Job & & $47 / 75$ yes & 3 \\
Generation on the & & 1.53 & $66 / 109$ yes \\
land** & & $39 / 74$ & 2.19 \\
Setting grew up in* & Rural & 28 & $77 / 110$ \\
& Suburban & 7 & 25 \\
Household & Urban & 14 & 8 \\
Income*** $(106)$ & $0-20 \mathrm{k}$ & & 2 \\
& $20-40 \mathrm{k}$ & 11 & 32 \\
& $40-60 \mathrm{k}$ & 19 & 32 \\
& $60-80 \mathrm{k}$ & 10 & 14 \\
& $80-100 \mathrm{k}$ & 6 & 12 \\
Formal Ag Training & $100 \mathrm{k}+$ & 11 & 14 \\
Acres farmed*** & & $30 / 72$ yes & $49 / 106$ yes \\
Percentage of & & 30.41 & 115.54 \\
Household Income & & $14(18.71 \%)$ & $27(24.53) \%$ \\
from farm & & & \\
\hline *p>.1; **p $>.05 ; * * * \mathrm{p}>.01 ; * * * * \mathrm{p}>.001$ & & \\
\hline
\end{tabular}

$3263.3 \quad$ Research Question: What variables most predict West Virginian farmers who sell

327 directly to consumers versus those who use non-direct venues such as wholesalers

328 distributing locally, local grocers, and restaurants?

329

330 First we compared results between the two groups on the two 1-7 point scales

331 (risks and economic factors). Results are presented in Tables 2 and 3. Secondly, we 
332 performed principal component analyses on each scale, respectively, to develop

333 composite scores for emergent factors.

334 A principal component analysis (presented in Table 2) on the battery of questions

335 related to risks detected the presence of three components with Eigenvalues greater than

336 one. Only the first component had a Cronbach's alpha score above .6, which is generally

337 the acceptable threshold (Hair et al., 1998). Bartlett's Test of Sphericity was significant at

338 the .000 level with a KMO test for sample adequacy at .846. The component is named

339 based on the components with heavy loading at .300 or greater. Component 1 had a

340 Cronbach's alpha score of .869 and explained 39.03\% of the variance. This component

341 included items related to concern for the production of high quality food, soil fertility,

342 pollution, health risks, willingness to try new farming practices, health of the land, and

343 interest in learning about new practices; we titled component 1 innovative-environmental

344 concern. Table 2 also highlights the scale items and corresponding $\mathrm{p}$-values between the

345 two groups. Six items returned significant results from the ANOVA, while two additional

346 items are noted as marginally significant.

347

Table 2. Between group comparison results and Principal Component Analysis for scale items pertaining to perspectives on production methods, farming philosophy, and risk acceptance.

\begin{tabular}{llll}
\hline $\begin{array}{l}\text { Please rate your level of agreement with } \\
\text { each of the following statements. Please } \\
\text { respond to each issue by marking the } \\
\text { appropriate box on the 1-7 (Fully Disagree } \\
\text { to Fully Agree) Scale. }\end{array}$ & Direct Mean & $\begin{array}{l}\text { ND or Combo } \\
\text { Mean }\end{array}$ & $\begin{array}{l}\text { Component } 1 \\
\alpha=.846\end{array}$ \\
\hline $\begin{array}{l}\text { I am concerned with the production of high } \\
\text { quality foods. }\end{array}$ & $6.78^{* * *}$ & $6.35^{* * *}$ & $\mathbf{. 0 3}$ \\
$\begin{array}{l}\text { Higher soil fertility is an important } \\
\text { consideration for me. }\end{array}$ & 6.27 & 5.96 & $\mathbf{. 7 0 6}$ \\
$\begin{array}{l}\text { I attempt to minimize pollution as much as } \\
\text { possible on the farm. }\end{array}$ & $6.54^{* * *}$ & $6.27^{* * *}$ & $\mathbf{. 8 3 8}$
\end{tabular}


Health risks associated with chemicals/farm applications are one of my concerns.

I am willing to adopt and try new and

$5.98 *$ .776 innovative farming practices.

The health of the land on my farm is extremely important to me.

I am interested in learning about new

farming techniques and practices.

The farmers I associate with use involve common herbicide and pesticide applications.

The existence of my farm is an important asset to my larger community.

The farmers I associate with use organic / $5.09 * * \quad 5.04 * * \quad .074$ sustainable farming techniques that do not involve common herbicide and pesticide applicants.

I hope my land continues to be farmed after I decide to stop farming.

I attempt to minimize off-the-farm inputs in

349 A principal component analysis (presented in Table 3) on the battery of questions

350 related to economic factors detected the presence of three components. All components

351 had a Cronbach's alpha score greater than .790, which is acceptable (Hair et al., 1998).

352 Bartlett's Test of Sphericity was significant at the .000 level with a KMO test for sample

353 adequacy at .825 . All components are named based on the items with heavy loading at

354.300 or greater. Component 1 had a Cronbach's alpha score of .785 and explained

$35534.83 \%$ of the variance. This component included items related to price premiums for

356 organic products, organic farming laws, governmental laws and regulations, payments to

357 organic farming, and changes in government support; we titled component 1

358 governmental support, certification, and policy. Component 2 had a Cronbach's alpha

359 score of .847 and explained $10.75 \%$ of the variance. This component included items 
360 relating to changes in technology, cost of credit, availability of loan funds, uncertainty

361 about family relationships, fire damages, and technical failure/malfunction of

362 machinery/equipment; we titled component 2 dependence and uncertainty. Component 3

363 had a Cronbach's alpha score of .736 and explained $8.36 \%$ of the variance (all three

364 components combined explain $53.95 \%$ of the variance). Component 3 items included

365 changes in consumer preferences, marketing and sales, cost of inputs, equipment costs,

366 changes in technology, and government laws and regulations; we titled component 3

367 market forces and change. Table 3 also highlights the scale items and corresponding p-

368 values between the two groups. Four items returned significant results from the ANOVA,

369 while two additional items are noted as marginally significant.

370

Table 3. Between group comparison results and Principal Component Analysis for scale items pertaining to issues related to farm economic performance. Significant variables are denoted with asterisks and retained components are in bold face.

\begin{tabular}{|c|c|c|c|c|c|}
\hline $\begin{array}{l}\text { How dependent do you consider } \\
\text { each of the following issues in } \\
\text { regard to the economic } \\
\text { performance of your farm? (The } \\
\text { scale is } 1=\text { No Dependency to } 7= \\
\text { Very Large Dependency) }\end{array}$ & $\begin{array}{l}\text { Direct } \\
\text { Mean }\end{array}$ & $\begin{array}{l}\text { ND or } \\
\text { Combo } \\
\text { Mean }\end{array}$ & $\begin{array}{l}\text { Component } \\
1 \\
\alpha=.854\end{array}$ & $\begin{array}{l}\text { Component } \\
2 \\
\alpha=.837\end{array}$ & $\begin{array}{l}\text { Component } \\
3 \\
\alpha=.797\end{array}$ \\
\hline Changes in consumer preferences & 4.90 & 5.20 & .103 & $\begin{array}{l}169 \\
\end{array}$ & .791 \\
\hline Marketing/sale & 4.94 & 5.38 & .118 & -.041 & .781 \\
\hline Costs of operating inputs & 4.96 & 5.12 & .043 & .111 & .558 \\
\hline Cost of capital equipment & 4.93 & 5.02 & .082 & .295 & .479 \\
\hline Changes in technology & $3.74 * *$ & $4.29 * *$ & .199 & .496 & .566 \\
\hline Cost of credit & $3.02 *$ & $3.61 *$ & .175 & .841 & .084 \\
\hline Availability of loan funds & $2.89 *$ & $3.44 *$ & .254 & .837 & .079 \\
\hline $\begin{array}{l}\text { Price premiums for organic } \\
\text { products }\end{array}$ & $4.46 * * *$ & $3.58 * * *$ & .853 & .032 & .112 \\
\hline $\begin{array}{l}\text { Organic farming laws and } \\
\text { regulations }\end{array}$ & $4.02 *$ & $3.42 *$ & .875 & .141 & .161 \\
\hline $\begin{array}{l}\text { Other government laws and } \\
\text { regulations }\end{array}$ & 4.46 & 4.59 & .536 & .360 & .381 \\
\hline $\begin{array}{l}\text { Additional government payments } \\
\text { to organic farming }\end{array}$ & 2.85 & 2.73 & .853 & .139 & .019 \\
\hline
\end{tabular}




\begin{tabular}{llllll}
$\begin{array}{l}\text { Changes in government support } \\
\text { payments }\end{array}$ & 2.86 & 3.19 & $\mathbf{. 6 0 0}$ & .184 & .023 \\
$\begin{array}{l}\text { Injury, illness or death of } \\
\text { operators }\end{array}$ & 5.45 & 5.46 & .133 & -.048 & .257 \\
$\begin{array}{l}\text { Health situation of others in the } \\
\text { farm family }\end{array}$ & $4.43 * * *$ & $5.31^{* * *}$ & .070 & .091 & .041 \\
$\begin{array}{l}\text { Uncertainty about family } \\
\text { relationships }\end{array}$ & 2.91 & 3.22 & .093 & $\mathbf{. 4 1 5}$ & -.147 \\
$\begin{array}{l}\text { Hired labor } \\
\begin{array}{l}\text { Fire damages } \\
\text { Technical failure/malfunction of } \\
\text { machinery and equipment }\end{array}\end{array}$ & 3.16 & 3.31 & .180 & .186 & .012 \\
\hline
\end{tabular}

$* \mathrm{p}>.1 ; * * \mathrm{p}>.05 ; * * * \mathrm{p}>.01 ; * * * * \mathrm{p}>.001$

371

372 The binary logistic regression results that evaluated factors affecting whether or

373 not an individual would distribute direct to consumers only or also through non-direct

374 channels provided 6 steps for interpretation (Table 4). Covariates in the model included

375 the composite score for the composite component innovative-environmental concern,

376 gender responsible for farming operations, the composite scores for the three economic

377 components in Table 3, education attainment level, acres being farmed, length of

378 ownership of the land, farm classification type, and years of direct involvement in the

379 farming operations. We chose to present Step 5 due to the combination of its significance

380 level, percentage accuracy, AIC and BIC scores, and inclusion of more variables than

381 other steps. The model fits the data well (Hosmer and Lemeshow Goodness of Fit Test

$382 p=0.578$ ), was significant at the .018 level, and met parameters to justify interpretation.

383 Five variables were significant, including the composite component dependence and

384 uncertainty, educational attainment level, length of ownership of the land, farm

385 classification type, and acres farmed. As an individual's dependence and uncertainty

386 score on technology, finance options, family relations, and other significant issues

387 increased, so did his or her likelihood of being a farmer who distributes through non- 
388 direct avenues vs. direct. As one's length of ownership and acres farmed increased, so did

389 the likelihood that person would distribute through non-direct means. Additionally, those

390 whose farms were classified as organic (non-certified) were more likely to distribute

391 through alternative means than direct to consumer. Finally, as one's educational level

392 increased, that person's likelihood of selling through non-direct means decreased.

Table 4. Summary statistics for binary stepwise logistic regression model in which farmers' distribution methods were regressed on 8 independent variables. Independent variables retained in step 5 are listed in order of their $\operatorname{Exp}(B)$ score, with asterisks denoting significance.

\begin{tabular}{|c|c|}
\hline$x^{2}$ & $\begin{array}{c}\text { Model } 1 \\
\text { Step } 5\end{array}$ \\
\hline Model Sign. & .018 \\
\hline Hosemer Lemeshow & .867 \\
\hline Chi-Square & 3.887 \\
\hline -2 Log Likelihood & 181.958 \\
\hline Nagelkerke & .237 \\
\hline Percentage Accuracy & $67.1 \%$ \\
\hline Akaike's Information Criterion (AIC) & 232.004 \\
\hline Bayesian Information Criterion (BIC) & 238.141 \\
\hline Variables & $B$ (S.E.; $\operatorname{Exp}(B)$ \\
\hline Farm Classification Type & $.556(.369 ; 1.744)$ \\
\hline Q15 F2- dependence and uncertainty & $.210(.127 ; 1.234)^{* *}$ \\
\hline Length of Ownership & $.016(.369 ; 1.016)^{* *}$ \\
\hline Acres Farmed & $.005(.002 ; 1.005)^{*}$ \\
\hline Education Level & $-.198(.088 ; .820)^{*}$ \\
\hline Constant & $-.233(.791 ; .792)$ \\
\hline
\end{tabular}

S.E. Standard Error; n.s. Not Significant.

394 $* * * * \mathrm{p}<.001 ; * * * \mathrm{p}<.01 ; * * \mathrm{p}<.05 ; * \mathrm{P}<.1$

$395 \quad$ 4. Discussion

$396 \quad 4.1 \quad$ Salient Ideas

397 This study, based on data from West Virginia farmers who are producing for local

398 distribution, explores vital questions concerning the similarities and differences between

399 farmers who "sell local," with some choosing only direct sale venues, while others also 
400 utilize intermediaries for distribution. Our results provide both support to prior studies

401 and new insights on an increasingly important issue as demand for local food continues to

402 outpace supply. As captured within our dichotomous comparisons and further

403 underscored by our regression analysis, three salient ideas stem from our results: (1)

404 demographic and farm differences exists between farmers selling only directly to

405 consumers and those using direct and those using non-direct distribution approaches; (2)

406 variations in farming philosophies exist between the two groups; and (3) variables

407 associated with farm economic stability vary between those distributing directly versus

408 those using non-direct methods.

409 Our results indicate that farmers who are distributing to restaurants, food hubs,

410 wholesalers, or other institutional buyers are demographically distinct from their direct-

411 only counterparts with regard to a number of measures: most critically, educational

412 attainment, acres farmed, and length of family ownership. Educational attainment was

413 inversely correlated to selling through non-direct means. While previous studies have

414 looked at the implications that education has for information-seeking and risk-taking

415 (Genius et al., 2006; Koesling et al., 2004), little work has been done on farmers'

416 demographics and their decisions to sell through various marketing channels. One

417 exception, Koesling et al. (2004), reported that post-secondary education reduces concern

418 about access to credit and the risks associated with credit. This coincides with our results,

419 which indicate that those selling only direct-to-consumer had higher educational

420 attainment, were less concerned with changes in technology, and were less dependent on

421 external financing options. This may be because these individuals are farming fewer

422 acres, which would likely result in less land debt (Lyson et al., 1995), and therefore they 
423 might view the farming experience as a lifestyle or hobby as opposed to a vocation

424 (Brown, 2002). If farming is a long-standing part of one's familial culture, the

425 development of the business and distribution strategies selected may be further developed

426 for those selling through non-direct means, as these farmers were more likely than their

427 counterparts to have a longer family tie to their land. This finding parallels that of Park

428 (2009), who found that years of experience were highly correlated with income, having a

429 positive affect amongst organic farmers. Taken together, these variables - land tenure and

430 education - point to the main issue of access to land and capital as determinants of scale

431 and, this research anticipates, marketing strategy. These two variables are critical, as

432 acres farmed are often linked to family ownership by the passing of farmland through

433 family lines. Furthermore, if one's family is in the business, then a business model may

434 be inherited along with the land, saving the farmer the financial and temporal strain of

435 beginning a new business.

436 Additionally, both our regression result and comparison analyses suggest that

437 several variables associated with one's farming philosophy were also found to be

438 distinctly different for the two groups. Prominent among these differences was the

439 innovative-environmental concern component from the PCA. This component highlights

440 that farmers only selling direct-to-consumer had greater concerns about how their

441 farming practices affected the environment, the production of high quality foods, and the

442 health risks associated with chemical usage; they were also more willing to try new

443 methods than their non-direct counterparts. Other scholars have found similar results

444 when comparing organic farmers to conventional farmers (Koesling et al., 2004; Läpple,

445 2012; Sullivan et al., 1996); however, there is a lack of research that compares farmers 
446 based on scaling levels or distribution strategies. That said, farm type (organic or

447 conventional) was retained in our regression model even though it was not significant.

448 Thus, one should interpret the overall result of this particular component with caution,

449 not drawing strict conclusions between farmers based on distribution model alone.

450 Further investigation of this issue is needed in other areas to better understand these

451 important variables that factor into farmers' decisions.

452 Component 2 from the economic dependence scale, which was significant in the

453 regression analysis, highlights the variation in the two groups when it comes to

454 dependence on costs of credit; availability of loans funds; family relations involved with

455 the farming operation; and uncertainty with changes in technology, fire damage issues,

456 and technical failure/malfunctioning of machinery and equipment. These findings

457 coincide with research previously done on farmers' decisions to participate in organic

458 agriculture and direct marketing, particularly in the area of technology and financing.

459 Feenstra et al. (2011) found that "[a]ccess to capital is closely related to scale" (p. 510).

460 With growing scale came an increased opportunity to capitalize and take risks on new

461 forms of marketing and distribution channels (ibid). Day-Farnsworth et al. (2009)

462 similarly argued that a lack of investment capital was a significant barrier keeping

463 farmers from participating in mediated sales, meaning wholesalers wanting to capture

464 price premiums for organic and local produce must work with farmers to aggregate,

465 process, and store produce.

466 Perhaps most surprisingly, our analysis found that non-certified organic farms

467 were more likely than conventional farms to use distribution models other than direct to

468 consumer. While Farmer et al. (2014) argued that economic motivations are largely 
469 responsible for farmers' adoption of organic practices, more seems to be at work here.

470 McCann et al. (1997) argued that organic farmers are more likely to define success in

471 terms of the profitability of their farm, while conventional farmers were more likely to

472 define success as simply "making a living." Further, Park (2009) found many organic

473 farmers use farmers' markets and roadside stands initially, then expand to CSAs or sales

474 to restaurants and grocers as their operation expands - a method that supports an

475 economic motivation of decision making, with expansion happening as access to capital

476 and marketing opportunities increase over time. However, only certified organic farmers

477 stand to gain from price premiums for their produce, as uncertified organic cannot be

478 branded, labeled, or sold as organic in the U.S. Uncertified organic farmers selling

479 directly to the consumer are able to benefit from values-based marketing, as the consumer

480 can see the product, participate, and speak with the farmer about his methods. This extra

481 labor and value-based advantage is lost in aggregation, and with it the ability to demand

482 price premiums from the wholesaler or grocer. Therefore, practicing organic agriculture

483 without seeking certification and without selling direct to consumers implies that more

484 than economic motivations are at work.

$485 \quad 4.2 \quad$ Limitations and Future Directions

486 There are several limitations to this study that should be considered in the

487 interpretation of the results and for future parallel research. First, though we attempted to

488 create an exhaustive list of potential farmers through our solicitation of contact

489 information, potential participants were indeed absent from our sample. Access or

490 availability of a conclusive list would enhance the research process and therefore the

491 generalizability of the results. While such a list does not currently exist in WV, or any 
492 other state to our knowledge, the development of comprehensive farm lists to include

493 small farms in addition to large farms would be fruitful. Additionally, we were unable to

494 account for non-response bias. Our survey resulted in a 29.2\% response rate. Though well

495 within the acceptable level for mailed surveys (Dillman et al., 2011), following up with

496 non-respondents via a brief phone interview or abridged mail survey would allow us to

497 test for differences in those who did and did not take part in the survey. The length of our

498 instrument, eight pages, may have also affected the response rate by causing participant

499 fatigue that led to attrition. Future research should also consider the issue of farmers who

500 distribute locally and the variables affecting capacity to distribute through non-direct

501 means. Broadening the population pool to those in other states and regions would allow

502 for important comparisons that take into account geographic differences, state rules and

503 policies, and valuable infrastructure in different regions that support industry differences.

\section{5. Conclusion}

506 Though small in scope, research such as this helps us to better understand the

507 variables that may affect farmers' capacity for scaling their operations to move beyond a

508 direct-to-consumer model, as well as the factors associated with why they may lack

509 interest, willingness, or motivation to do such. While our direct-to-consumer farmers

510 were found to indicate a greater willingness to try new approaches to farming, stronger

511 concern for the environment, and noted more of a concern with the health risks associated

512 with conventional chemical approaches to growing, they were also less concerned with

513 issues that are more pressing for larger farms, such as the availability of loans and the

514 cost of technological advances. In West Virginia and among our respondents specifically, 
515 critical distinctions exist between farmers selling directly to consumers versus those

516 using non-direct approaches — distinctions that are strongly linked to an individual's

517 history and heritage.

518

519 


\section{ACKNOWLEDGMENTS}

521 We thank Matthias Koesling, Martha Ebbesvik, Gudbran Lien, Ola Flaten, Paul Steinar

522 Valle, and Halvard Arntzen for letting us adapt their instrument for use in our research.

523 We thank expert panelists for their feedback on our instrument or assistance on the

524 research: farmer Tim Alexander, Dr. Tim Woods, farmer Dominique Wong, farmer Dr.

525 Jennifer Robinson, Dr. Jim Kotcon, Laura Hartz, Megan Granfiled, Anne Stroud, and

526 Justin Wolfe. We also thank Downstream Strategies of Morgantown, WV USA for

527 collaborating on this project and Justin Wolfe for his editing assistance. We also

528 appreciate the feedback and direction from Professor Caloran (Associate Editor for

529 Journal of Rural Studies) and the three anonymous reviewers. Finally, we thank the

530 United States Department of Agriculture, National Institute of Food and Agriculture for 531 financial support of this project. 


\section{REFERENCES}

Alkon, A. H. (2008). From value to values: Sustainable consumption at farmers markets. Agriculture and Human Values, 25(4), 487-498. http://doi.org/10.1007/s10460-0089136-y

Allen, P. (2010). Realizing justice in local food systems. Cambridge Journal of Regions, Economy and Society, 3, 295-308. http://doi.org/10.1093/cjres/rsq015

Brown, A. (2002). Farmers' market research 1940-2000: An inventory and review. American Journal of Alternative Agriculture, 17(4), 167-176. http://doi.org/10.1079/AJAA2002167

Campbell, A. M., \& MacRae, R. (2013). Local food plus: The connective tissue in local/sustainable supply chain development. Local Environment, 18(5), 557-566. http://doi.org/10.1080/13549839.2013.788488

Connell, D. J., Smithers, J., \& Joseph, A. (2008). Farmers' markets and the "good food" value chain: a preliminary study. Local Environment, 13(3), 169-185. http://doi.org/10.1080/13549830701669096

Cranfield, J., Henson, S., \& Holliday, J. (2010). The motives, benefits, and problems of conversion to organic production. Agriculture and Human Values, 27, 291-306. http://doi.org/10.1007/s10460-009-9222-9

Creswell, J. W., \& Clark, V. L. (2007). Designing and Conducting Mixed Methods Research. Thousand Oaks, California: SAGE Publications, Inc. 
Day-Farnsworth, L., McCown, B., Miller, M., \& Pfeiffer, A. (2009). Scaling up: Meeting the demand for local food. Madison, Wisconsin: UW-Extension Ag Innovation Center \& UW-Madison Center for Integrated Agricultural Systems.

Detre, J. D., Mark, T. B., Mishra, A. K., \& Adhikari, A. (2011). Linkage between direct marketing and farm income: A double-hurdle approach. Agribusiness, 27(1), 19-33. http://doi.org/10.1002/agr.20248

Dillman, D. A., Smyth, J. D., \& Melani, L. (2011). Internet, mail, and mixed-mode surveys: the tailored design method. Toronto: Wiley \& Sons.

Dimitri, C., \& Oberholtzer, L. (2009). Marketing U.S. organic foods: Recent trends from farms to consumers. (Economic Information Bulletin No. 58) Washington, D.C.: United States Department of Agriculture.

Dimitri, C., \& Greene, C. (2000). Recent growth patterns in the U.S. organic foods market. (Agriculture Information Bulletin 777). Washington, D.C.: United States Department of Agriculture.

Fairweather, J. R., \& Campbell, H. (1996). The decision making of organic and conventional agricultural producers. (Research report no. 233). Canterbury, New Zealand: Lincoln University Agribusiness and Economics Research Unit.

Farmer, J.R., Peters, C., Hansen, E. Boettner, F., Betcher, M. (2013). Overcoming the market barriers to organic production in West Virginia. Retrieved from 
http://www.downstreamstrategies.com/documents/reports_publication/overcoming _ market_barriers_to_organic_production_in_wv.pdf.

Farmer, J.R., Chancellor, C., Robinson, J.M., West, S., \& Weddle, S. (2014). Agrileisure: Farmers' markets, CSAs, and the privilege in eating local. Journal of Leisure Research, 46(3), 313-328.

Farmer, J. R., Epstein, G., Watkins, S. L., \& Mincey, S. K. (2014). Organic farming in West Virginia: A behavioral approach. Journal of Agriculture, Food Systems, and Community Development. http://doi.org/10.5304/jafscd.2014.044.007

Feenstra, G., Visher, D., \& Hardesty, S. (2011). Developing values based distribution networks to enhance the prosperity of small and medium sized producers. Davis, California: University of California Agricultural Sustainability Institute.

Galt, R., O’Sullivan ,L., Beckett, J., \& Hiner, C.C. (2012). Community Supported Agriculture Is Thriving in the Central Valley. California Agriculture 66(1), 8-14.

Genius, M., Pantzios, C. J., \& Tzouvelekas, V. (2006). Western Agricultural Economics Association Information Acquisition and Adoption of Organic Farming Practices. Journal of Agricultural and Resource Economics Western Agricultural Economics Association Journal of Agricultural and Resource Economics, 31(1), 93-113.

Greene, J. C., Caracelli, V. J., \& Graham, W. F. (1989). Toward a conceptual framework for mixed-method evaluation designs. Educational evaluation and policy analysis, 11(3), 255-274. 
Hanson, J., Dismukes, R., Chambers, W., Greene, C., \& Kremen, A. (2004). Risk and risk management in organic agriculture: Views of organic farmers. Renewable Agriculture and Food Systems, 19(4), 218-227. http://doi.org/10.1079/RAFS200482

Hair, J. F., Jr., Anderson, R. E., Tatham, R. L., \& Black, W. C. (1998). Multivariate data analysis (5th ed.). Upper Saddle River, NJ - Prentice Hall.

Hardesty, S. D., \& Leff, P. (2009). Determining marketing costs and returns in alternative marketing channels. Renewable Agriculture and Food Systems, 25(1), 24-34. http://doi.org/10.1017/S1742170509990196

Hinrichs, C. C. (2003). The practice and politics of food system localization. Journal of Rural Studies, 19, 33-45.

Johnson, N. R., \& Endres, A. B. (2012). Small producers, big hurdles: Barriers facing producers of "local foods." Hamline Journal of Public Law and Policy, 33, 49-122. Retrieved from http://ssrn.com/abstract=2225440

Koesling, M., Ebbesvik, M., Lien, G., Flaten, O., Valle, P. S., \& Arntzen, H. (2004). Risk and risk management in organic and conventional cash crop farming in Norway. Food Economics - Acta Agriculturae Scandinavica, Section C, 1(4), 195-206. http://doi.org/10.1080/16507540410019692

Läpple, D. (2012). Comparing attitudes and characteristics of organic, former organic and conventional farmers: Evidence from Ireland. Renewable Agriculture and Food Systems, 28(4), 329-337. http://doi.org/10.1017/S1742170512000294 
LeRoux, M. N., Schmit, T. M., Roth, M., \& Streeter, D. H. (2010). Evaluating marketing channel options for small-scale fruit and vegetable producers. Renewable Agriculture and Food Systems, 25(1), 16-23.

http://doi.org/10.1017/S1742170509990275

Lyson, T. A., Gillespie, G.W., \& Hilchey, D. (1995). Farmers' markets and the local community: Bridging the formal and informal economy. American Journal of Alternative Agriculture, 10(3), 108-113.

Marsden, T., Banks, J., \& Bristow, G. (2000). Food Supply Chain Approaches: Exploring their Role in Rural Development. Sociologia Ruralis, 40(4), 424-438.

McCann, E., Sullivan, S., Erickson, D., \& De Young, R. (1997). Environmental awareness, economic orientation, and farming practices: A comparison of organic and conventional farmers. Environmental Management, 21(5), 747-758. http://doi.org/10.1007/s002679900064

Paloviita, A. (2010). Consumers' sustainability perceptions of the supply chain of locally produced food. Sustainability, 2, 1492-1509. http://doi.org/10.3390/su2061492

Park, T. A. (2009). Assessing the returns from organic marketing channels. Journal of Agricultural and Resource Economics, 34(3), 483-497.

Peters, C., Hansen, E., Clingerman, J., Hereford, A., and Askins, N. (2012). Opportunities and constraints in local food supply chains. Beckley, West Virginia: West Virginia Food \& Farm Coalition. 
Shi, Y.J., Phipps, T.T., and Colyer, D. (1997). Agricultural land values under urbanizing influences. Land Economics, 73(1), 90-100.

Sullivan, S., McCann, E., De Young, R., and Erickson, D. (1996). Farmers' attitudes about farming and the environment: a survey of conventional and organic farmers. Journal of Agricultural and Environmental Ethics, 9(2), 123-143.

USDA. (2013). Commodity Areas: Definition of Specialty Crops. Retrieved from http://www.ams.usda.gov/AMSv1.0/scbgpdefinitions

USDA. (2007a). 2007 Census of Agriculture: Small Farms. Retrieved from http://www.agcensus.usda.gov/Publications/2007/Online_Highlights/Fact_Sheets/ Farm_Numbers/small_farm.pdf.

USDA. (2007b). Historical highlights: 2007 and earlier Census Years: West Virginia. Retrieved from http://www.agcensus.usda.gov/Publications/2007/Full_Report/Volume_1, _Chapter_1_State_Level/West_Virginia/st54_1_001_001.pdf

Verhaegen, I., \& Van Huylenbroeck, G. (2001). Costs and benefits for farmers participating in innovative marketing channels for quality food products. Journal of Rural Studies, 17, 443-456. http://doi.org/10.1016/S0743-0167(01)00017-1

Veldstra, M. D., Alexander, C. E., \& Marshall, M. I. (2014). To certify or not to certify? Separating the organic production and certification decisions. Food Policy, 49, 429436. http://doi.org/10.1016/j.foodpol.2014.05.010 
Winter, M. (2003). Embeddedness, the new food economy and defensive localism. Journal of Rural Studies, 19, 23-32.Wu, Olivia. 2005. "ENVIRONMENT IN FOCUS / Diet for a Sustainable Planet / The Challenge: Eat Locally for a Month (You Can Start Practicing Now).”SFGate, June 1. http://www.sfgate.com/green/article/ENVIRONMENT-IN-FOCUS-Diet-for-asustainable-2630631.php. 